\title{
OBSERVATIONS AT A YELLOW-BELLIED SAPSUCKER NEST
}

JEAN BANCROFT, 306-200 Tuxedo Avenue, Winnipeg, Manitoba. R3P OR3

On many occasions over the years at Whytewold (southern end of Lake Winnipeg) I have observed Yellow-bellied Sapsuckers. Until summer 1984, however, I was never fortunate enough to follow an entire nesting period. In our area the male bird's arrival in spring is made known by its cries and drumming on metal chimneys and garbage cans. This can be irritating to a cottager, especially when the persistent noise sometimes begins as early as 0500 h. By this means the bird establishes its territory, warns off competitors, and attracts a female.

On 14 May I first noticed a male drilling a hole approximately $5.4 \mathrm{~m}$ from the ground in an old aspen poplar, a tree with only a few leafy branches at its top. It stood in front of a cottage among several ash trees and saskatoon bushes. Sapsuckers seem to choose trees affected with tinder fungus (Fomes ignarius), preferably aspen poplars; this fungus attacks heartwood and makes excavation much easier. ${ }^{10}$

As it is generally known that sapsuckers do not use every hole they excavate, I visited this site frequently in order to determine if it would be used for nesting. One authority states that the hole is "bored by both sexes, but mostly by the male" and that it "takes 15-28 days" to drill.6 Brewster, in Bent, states that the "sexes work alternately... a week or more is occupied in the completion of the nest...A small quantity of the finer chips are left at the bottom to serve as a bed for the eggs." 2 The diameter of this particular hole was about $4.2 \mathrm{~cm}$. Inside measurements are reported as about 35 $\mathrm{cm}$ in depth and $12 \mathrm{~cm}$ in diameter. ${ }^{7}$
It was not until 1 June that I noticed a female fly into the nest hole. For the next few days I did not see either male or female at the hole; I heard and saw, on numerous occasions, only the male which was tapping nearby.

During the entire nesting period the male drummed, sometimes for long periods, on a sheet of plywood used for playing basketball and attached to a large oak, approximately $30 \mathrm{~m}$ from the nest site. The bird always drummed on the edges of the board "in a broken series prrrrrrrp, prrp, prp, prp" as described by Reed. ${ }^{9}$ On 4 June at $1030 \mathrm{~h}$ the male, after giving his call, flew onto the stump of a cut-off branch a few $\mathrm{cm}$ below the cavity, then darted across the road into a wooded area, returned, repeated his call and then flew to the board where he began drumming again. This was a frequent pattern, interspersed at times with long stretches of vigorous preening on a nearby ash tree.

On 9 June I watched the male fly to the same perch below the cavity and cling to it for several minutes, remaining perfectly quiet and motionless except when he turned his head to look up at the hole; the female also had this habit. Two days later, at $0800 \mathrm{~h}, \mathrm{I}$ observed the male peer into the cavity before squeezing himself into it. A few days later the male flew to the hole, peered into it and then proceeded to put his head inside the opening 12 times. He then pecked at the inside of the hole to widen it. Brewster also mentions that "so small indeed was this entrance in proportion to the size of the bird, that in many cases they were obliged to struggle violently for several seconds in either 
going out or in."'2 On 19 June, when I arrived at the site, I heard tapping coming from within the cavity. After a moment the male's head protruded from the hole and he threw out fine wood chips.

In spite of regular visits (up to three times daily) I was unable to determine the exact date when incubation began. Both male and female are said to incubate the three to seven white eggs. ${ }^{5}$ Forbush, in Bent, gives the incubation period [by both sexes] as "probably 14 days." 2 Bent says "as is the case of most nestling birds reared in a hole in a tree, little is known of the young sapsuckers while they are in the nest." 2

On 3 July, from 0755 to $0805 \mathrm{~h}$ both male and female fed the young. Later in the day the male flew out with a fecal sac, dropped it, and then rubbed his bill on the bark of the nearby ash tree; then he flew back into the cavity. The male and female took turns brooding and feeding the young. When one gave its call at the cavity entrance, the other would fly out and the first would immediately go in. On 16 July both parents were still going completely into the cavity. The next day, at $1600 \mathrm{~h}$, young were heard calling for the first time. By 22 July their calls had become quite audible. At $1210 \mathrm{~h}$ that day the male flew out with a fecal sac. The next day, when the female came with an insect in her bill, she went only part way into the hole. By 24 July the young in the cavity could be heard $15 \mathrm{~m}$ away.

On 1 August at $1017 \mathrm{~h} \mathrm{I} \mathrm{noticed} \mathrm{the}$ male drop an insect just inside the opening. Two youngsters were struggling to come to the entrance. Finally, at $1600 \mathrm{~h}$ one youngster's head protruded from the

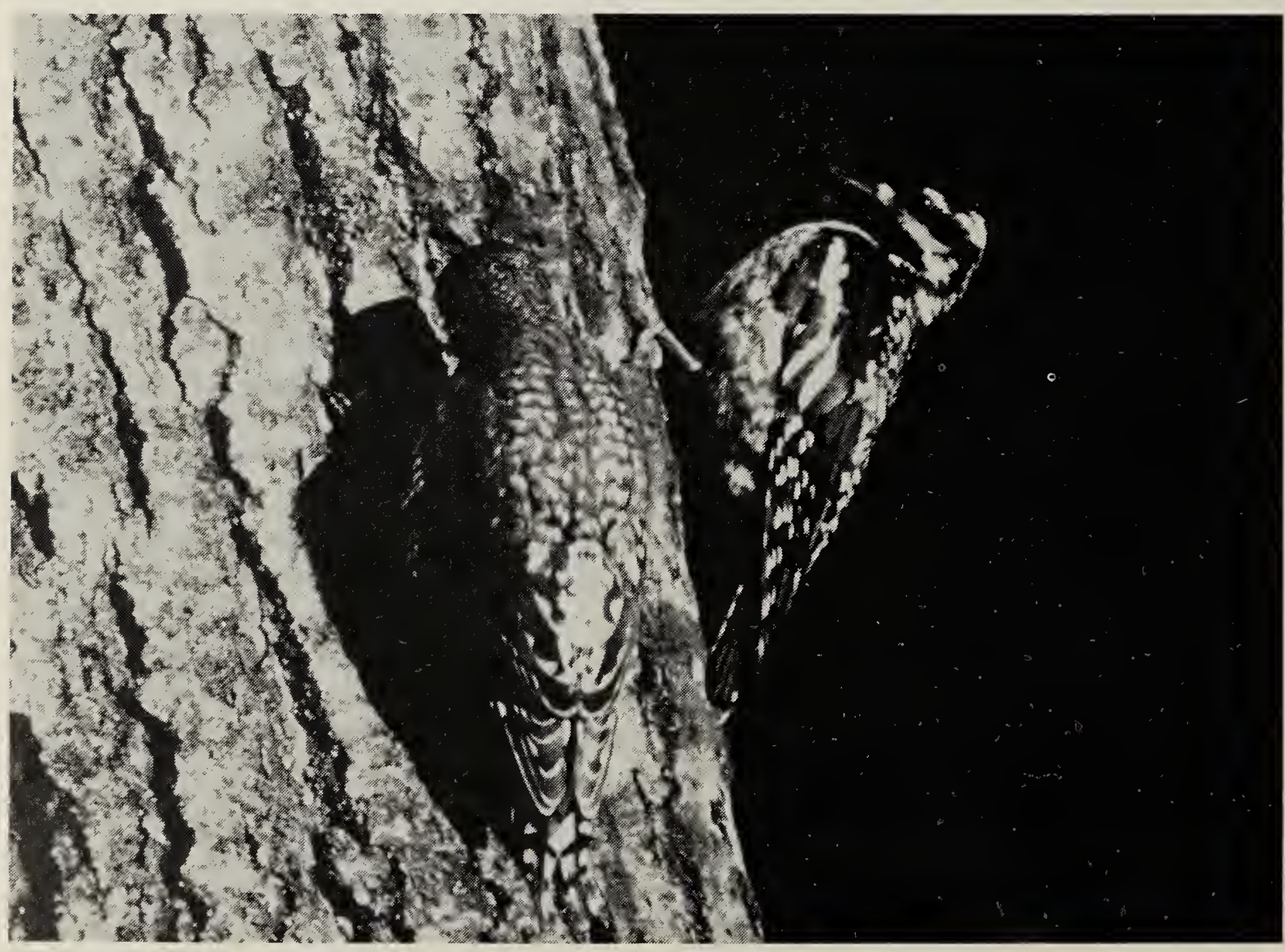

Yellow-bellied Sapsucker

Fred W. Lahrman 
hole. The nestling period proved to be a lengthy one. Harrison notes that the nestlings "climb to upper nest for feeding by 18 days, to entrance by 20 days. Leave at 25-29 days. "6 On 4 August, when I visited the site again, no sapsuckers were in sight, but on 6 August at $0945 \mathrm{~h}$ a male was pecking at an ash tree $15 \mathrm{~m}$ away. After that date no more sapsuckers were seen or heard. After the nesting period these birds are "comparatively silent."

The feeding habits of the Yellow-bellied Sapsucker are interesting. Although they belong to the woodpecker family "they lack the long extensile tongue which enables the other species to probe the winding galleries of wood-eating larvae." Their diet consists mainly of insects and sap, with fruit on occasion. In this particular case, both male and female drilled in two nearby ash trees, eventually stripping large pieces of bark down to the bare trunk. Saskatoon bushes nearby had circular drilling in several rows. Dennis states that "the holes are drilled primarily for sap...The birds also consume any small insects that they can easily catch near the holes or that sometimes drown in the sap."

Many years ago we found that after sapsuckers had attacked several of our Saskatoon bushes at Whytewold these bushes eventually died. Others have noted that these birds can cause trees to die. ${ }^{1}$ McAtee, in Bent, states that the Yellowbellied Sapsucker "must be included in the class of injurious species." 2 Not all authorities, however, agree that trees are endangered by sapsuckers. ${ }^{8}$ Sapsuckers are also beneficial. Through their sap wells, says Dennis, "they provide the only source of food that is readily available to other birds. Ruby-throated Hummingbirds time their spring migration into the still leafless, wintry northlands not to coincide with early wildflowers, but sap flowing from sapsucker diggings... Warblers and other small birds become dependent upon sapsuckers when flying insects are unavailable. The services that sapsuckers render should make us feel more kindly toward this droll, sometimes destructive bird." "4 Knapton et al. reported hummingbirds even following sapsuckers in order to find their diggings. ${ }^{8}$

1 BANCROFT, J. 1965. Damage to trees by sapsuckers. Blue Jay 23:107.

2 BENT, A.C. 1964. Life histories of North American woodpeckers. Dover N.Y. 334 pp.

3 DAVIE, O. 1898. Nests and eggs of North American birds. Musson Book Co. Ltd., Toronto. 509 pp.

4 DENNIS, J.V. 1981. Beyond the bird feeder. A.A. Knopf, Inc. New York, N.Y. 201 pp.

5 GODFREY, W.E. 1966. The birds of Canada. Nat. Mus. Canada Bull. 203.428 pp.

6 HARRISON, C. 1978. A field guide to the nests, eggs and nestlings of North American birds. William Collins \& Sons, Glasgow. 416 pp.

7 HARRISON, H.H. 1975. A field guide to birds' nests in the United States east of the Mississippi River. Houghton Mifflin, Boston. 257 pp.

8 KNAPTON. R.W., R.V. CARTAR and J.D. REYNOLDS. 1985. Do hummingbirds follow sapsuckers to food sources? Blue Jay 43:186-187.

9 REED, C.A. 1922. Land birds east of the Rockies. Doubleday, Page, Garden City, New York. 228 pp.

10 UDVARDY, M.D.F. 1977. The Audubon Society field guide to North American Birds (western region). A.A. Knopf, New York. 853 pp.

1 U.S. DEPT. AGRI., FOREST SERVICE. 1977. Cavity-nesting birds of North American forests. U.S. Gov't. Printing Office, Washington, D.C. 112 pp. 